\title{
PENGARUH PENAMPILAN MODIS TERHADAP PENGEMBANGAN KARIR KARYAWAN PEREMPUAN PADA BANK DANAMON CABANG PEKANBARU
}

\author{
Ainun Mardiah \\ Fakultas Ekonomi dan Ilmu Sosial UIN Suska Riau \\ ainun_pkb@yahoo.com
}

\begin{abstract}
Fashionable and attractive appearance is a requirement that priority for employees in the banking world. Fashionable appearance is always interpreted as a way of dress, makeup, lifestyle, and selfactualization as a whole is quite attached to women employees in public life. Research conducted on 30 female employees at PT Pekanbaru Danamon Bank. It focuses on the issue of whether the appearance of fashionable significant effect on female employees' career development. The results showed that the appearance of fashionable significant impact on employee career development of women in PT Pekanbaru Damon Bank.
\end{abstract}

Kata Kunci : $\quad$ Penampilan modis, pengembangan karir, karyawan. 
Penampilan seorang karyawan perusahaan seolah telah menjadi hal yang sangat penting dan dituntut perusahaan kepada para pegawai maupun calon pegawainya. Hal ini dapat dilihat dari iklan-iklan lowongan kerja yang pada umumnya mencantumkan "penampilan menarik" sebagai salah satu persyaratan yang harus dipenuhi oleh para pelamar kerja, terutama pelamar kerja perempuan.

Bank Danamon sebagai salah satu bank swasta di Indonesia, juga memiliki beberapa peraturan yang mengatur tata cara penampilan dan buku panduan yang mengatur beberapa cara berpakaian, jenis kosmetik, perhiasan yang boleh atau tidak boleh digunakan oleh para karyawannya. Selain itu, penampilan ramah, senyum, dan beberapa gerakan tubuh juga diatur dan menjadi kriteria penting dalam memberikan penilaian pada setiap karyawan Bank Danamon.

Itulah sebabnya, selama ini kebanyakan masyarakat beranggapan bahwa penampilan karyawan bank lebih menarik dibanding penampilan karyawan di lingkungan kerja yang lain. Penampilan karyawan bank dengan seragam yang pada umumnya mengenakan blazer dan rok pendek bagi karyawan perempuan memberikan kesan elegan, rapi, dan berwibawa.

Seluruh karyawan bank Danamon, khususnya karyawan perempuan, dituntut untuk dapat berpenampilan menarik. Hal ini disebabkan karena pekerjaan sebagai karyawan bank merupakan pekerjaan yang memiliki intensitas cukup tinggi untuk berinteraksi dengan orang lain yang disebut sebagai nasabah. Sehingga profesionalisme kerja mesti dijaga untuk memberikan layanan terbaik kepada nasabah.

Berdasarkan hasil survei Marketing Research Indonesia (MRI), Bank Mandiri menempati posisi terdepan dalam hal layanan prima (The Best Bank Service Excellence 2008). Misi pengukurannya adalah untuk memacu industri perbankan agar memberikan pelayanan yang terbaik bagi nasabah. The Best Bank Service Excellence ini melibatkan pengamatan pada sarana penunjang, seperti kondisi gedung, penyediaan berbagai fasilitas dan kondisinya, seperti toilet dan ATM. Hal-hal lain yang diamati adalah unsur-unsur yang penting bagi pelanggan. Unsur karyawan juga merupakan hal yang penting diamati, misalnya meliputi keramahan, ketrampilan dan penampilan karyawan. Hasilnya, berturut-turut untuk kelompok bank umum posisi 10 besar adalah Bank Mandiri, BII, Bank CIMB Niaga, Bank OCBC NISP, Bank Danamon, BCA, BNI, Permata Bank, Bank Bukopin dan Citibank ${ }^{1}$ 
Dari data ini terlihat bahwa Bank Danamon masih menempati urutan kelima dan posisi teratas dipegang oleh Bank Mandiri. Dari hasil survei ini tentunya Bank Danamon diharap bisa meningkatkan pelayanannya kepada nasabah yang meliputi keramahan, ketrampilan dan penampilan karyawan sehingga ditahun mendatang mampu menduduki posisi teratas dalam pelayanan.

Berdasarkan dari hasil survei Marketing Research Indonesia di atas, dapat diketahui bahwa penampilan seorang karyawan Bank Danamon merupakan salah faktor yang sangat penting karena apabila karyawan bank memiliki penampilan yang sempurna maka nasabah pun lebih merasa nyaman untuk berinteraksi dan bertransaksi di Bank Danamon. Penampilan yang dapat dikatakan sempurna, yakni penampilan modis serta pelayanan yang baik kepada nasabah.

Sebagian orang yang mengatakan bahwa selain pintar, penampilan itu harus enak dilihat, bukan harus cantik, namun ada sebagian orang yang mengatakan bahwa penampilan itu tergantung dari bidang apa yang ditekuni. Kalau pegawai lapangan, lebih baik mengutamakan penampilan yang lebih santai namun tetap sopan. Hal terpenting dalam berpenampilan di kantor ialah bahwa penampilan yang ditunjukkan harus profesional sesuai dengan bidang pekerjaannya. Mengenakan pakaian yang tepat merupakan keharusan jika seorang karyawan ingin dihargai di lingkungan kerjanya. Kecenderungan masyarakat yang memandang seseorang berdasarkan kesan pada pandangan pertama tidak dapat diabaikan begitu saja².

Banyak masyarakat berpendapat bahwa karyawan perempuan harus berpenampilan modis diartikan sebagai cara berpakaian, tata rias, gaya hidup "branded" (menggunakan barang-barang yang memberi arti pada posisi kelas tertentu) dan aktualisasi diri secara keseluruhan karyawan perempuan di Bank Danamon yang dapat terlihat elegan, up to date (selalu mengikuti perkembangan mode), dan penampilan yang good looking ini memang cukup melekat dalam kehidupan masyarakat. Pencitraan yang selalu berkaitan dengan seksualitas, yakni penampilan perempuan yang digambarkan elegan, up to date, dan penampilan yang good looking kemudian menjadi isu yang berkaitan dengan pengembangan karir di kantor.

Isu gender yang kemudian muncul pada profesi sebagai karyawan bank adalah ketika perempuan dijadikan sebagai "alat" untuk menarik perhatian nasabah. Dalam dunia perbankan, perempuan menjadi bagian dari seluruh kinerja. Gaya luwes dan lebih detail ketika melayani nasabah membuat mereka menjadi penjaga di barisan terdepan. Hal ini terbukti 
dan terlihat di posisi frontliner yang lebih banyak diduduki oleh karyawan perempuan ini menimbulkan bias gender pada bidang pekerjaan di perbankan sebab perempuan dipandang lebih pantas untuk mengisi jabatan frontliner karena penampakan luar yang lebih menarik dibanding laki-laki, dan juga citra perempuan yang identik dengan kelembutan dan keramahan. Stereotype muncul pada profesi karyawan perempuan dimana karyawan perempuan dituntut untuk berpenampilan modis, khususnya peraturan mengenai tata rias yang tidak ditekankan pada karyawan pria.

Karyawan perempuan di industri perbankan juga rentan terhadap beberapa isu gender lainnya, seperti beban ganda yang diembannya. Perempuan bertanggung jawab dalam keluarga dan karier, hal ini terkadang menghambat proses pencapaian karier perempuan itu sendiri. Tuntutan untuk berpenampilan modis bagi karyawan perempuan, sementara sebelum berangkat bekerja perempuan bertanggung jawab lebih dulu untuk mengurus keluarga sehingga waktu mereka hanya sedikit untuk mempersiapkan penampilan yang lebih optimal di kantor.

Bagi karyawan Bank Danamon, cara berpakaian dan berpenampilan telah diatur, yakni menggunakan seragam berupa atasan jas dan celana panjang bagi para karyawan wanita, sepatu berwarna gelap (hitam atau coklat), tidak menggunakan aksesoris berlebihan, rambut ditata rapi, warna make up yang kecoklatan atau cenderung gelap. Bagi pegawai pria diharuskan menggunakan kemeja berlengan panjang yang juga merupakan seragam.

Untuk tampil menawan di kantor tentu saja butuh kualitas tertentu. Syarat utamanya adalah berani tampil beda. Bukan berarti karyawan dituntut mengenakan busana yang "norak" atau lain dari yang lain, melainkan membuat orang lain, terutama atasan, menyadari bahwa selera karyawannya setingkat lebih tinggi dibanding karyawan lainnya. ${ }^{3}$

Selain penampilan berbusana, penampilan fisik tidak bisa dipungkiri untuk mendapatkan salah satu penilaian dari tempat kerja. Sehingga tidaklah mengherankan bila karyawan bank selalu menjaga penampilan, bahkan "mendongkrak" penampilan, karena itu dianggap merupakan salah satu cara untuk peningkatan jenjang karier secara tidak langsung. Anggapan bahwa karyawan bank perempuan berpenampilan modis lebih dominan untuk mengembangkan karir mewarnai persaingan kerja di perbankan. Karyawan perempuan yang berpenampilan modis ini kemudian diasumsikan lebih mudah bergaul, dan mudah memasuki kelas sosial para atasan sehingga mereka lebih mudah dalam mengembangkan karirnya. 
Dalam penelitian ini, penulis mengkaji tentang pengaruh penampilan modis terhadap pengembangan karir karyawan perempuan pada Bank Danamon Cabang Pekanbaru. Permasalahan yang menjadi fokus kajian adalah apakah penampilan modis berpengaruh signifikan terhadap pengembangan karir karyawan perempuan pada Bank Danamon Cabang Pekanbaru?

\section{METODE}

Penelitian ini dilaksanakan di Bank Danamon Cabang Pekanbaru dengan menggunakan metode analisis regresi linier sederhana. Populasi adalah seluruh karyawan perempuan pada Bank Danamon Cabang Pekanbaru yang berjumlah 30 orang dan semuanya dijadikan sampel (sensus sampling).

Data primer adalah data yang diperoleh dalam bentuk baku dan masih membutuhkan pengolahan lebih lanjut. Data ini berisikan antara lain pendapat seluruh karyawan perempuan pada Bank Danamon Cabang Pekanbaru tentang penampilan dan pengembangan karir. Sedangkan data sekunder adalah data dan informasi pendukung yang diperoleh dari Bank Danamon Cabang Pekanbaru. Teknik pengambilan data adalah wawancara dan kuesioner. Kuesioner sebagai instrumen pengumpulan data, disusun dengan menggunakan skala Likert. Setiap pertanyaan mempunyai lima alternatif jawaban. Maka untuk itu ditetapkan bobot bagi alternatif jawaban yang dipilih. Alternatif jawaban pertama (a) diberi skor 5, alternatif jawaban kedua (b) diberi skor 4, alternatif jawaban ketiga (c) diberi skor 3, alternatif jawaban keempat (d) diberi skor 2, alternatif jawaban kelima (e) diberi skor 1.

Sebelum penelitian dilakukan, perlu dilakukan pengujian terhadap validitas dan reliabilitas terhadap daftar pertanyaan yang digunakan. Pengujian validitas dan reliabilitas daftar pertanyaan ini dimaksudkan agar daftar pertanyaan yang digunakan untuk mendapatkan data penelitian, memiliki tingkat validitas dan reliabilitas memenuhi batasan yang disyaratkan.

Uji validitas daftar pertanyaan dilakukan dengan tujuan untuk mengetahui kehandalan angket. Kehandalan angket mempunyai arti bahwa angket mampu mengukur apa yang seharusnya diukur. Terdapat tiga jenis validitas yang dapat diterima secara umum yaitu validitas isi, validitas konstruk dan validitas yang berkaitan dengan kriteria. Dalam penelitian ini uji validitas yang digunakan adalah uji validitas konstruk yang mengkorelasikan skor masing-masing item pertanyaan dengan skor totalnya. Sedangkan uji reliabilitas merupakan uji kehandalan yang 
bertujuan untuk mengetahui seberapa jauh suatu alat ukur dapat diandalkan atau dipercaya. Kehandalan berkaitan dengan estimasi sejauh mana suatu alat ukur dilihat dari stabilitas atau konsistensi internal dari informasi, jawaban atau pernyataan, jika pengukuran dilakukan atau pengamatan dilakukan berulang. Apabila suatu alat ukur digunakan berulang dan hasil yang diperoleh relatif konsisten maka alat ukur tersebut dianggap handal (reliabel). Uji reliabilitas menunjukkan sejauh mana suatu alat ukur dapat memberikan hasil yang relative sama apabila dilakukan pengukuran kembali pada obyek yang sama. Nilai reliabilitas minimum dan indikator pembentuk variable laten yang dapat diterima adalah sebesar 0,60 .

Variabel penelitian terdiri dari variabel bebas yaitu penampilan modis $(X)$ dan variable terikat yaitu pengembangan karir $(Y)$.

Teknik analisis data yang digunakan dalam penelitian ini adalah analisis regresi linier sederhana. Bertujuan untuk meneliti pengaruh diantara variabel indenpenden terhadap variabel dependen, dengan formulasi : $\mathbf{Y}=\mathbf{a}+\mathbf{b X}$.

Dimana : $a$ adalah konstanta, $b$ adalah koefisien regresi, $X$ adalah penampilan modis dan $Y$ adalah pengembangan karir.

\section{TINJAUAN TEORITIS}

\section{Teori Pengembangan Karir}

Pengembangan karier, menurut Rivai, ${ }^{4}$ adalah proses peningkatan kemampuan kerja individu yang dicapai dalam rangka mencapai karier yang diinginkan. Tujuan dari seluruh program pengembangan karier adalah untuk menyesuaikan antara kebutuhan dan tujuan karyawan dengan kesempatan karier yang tersedia di pemerintahan saat ini dan dimasa mendatang.

Kinerja, pengalaman, dan kadang-kadang keberuntungan, berpengaruh terhadap pencapaian karier individu. Dengan demikian, pengembangan karier merupakan tindakan seseorang pegawai untuk rencana kariernya. Tindakan ini bisa didukung oleh kepala bagian Sumber Daya Manusia atau pihak lain.

Manfaat yang diperoleh dari pengembangan karir SDM tersebut antara lain adalah (1) mendorong para karyawan untuk mengembangkan diri dan kemampuannya, (2) menambah rasa kepedulian yang tinggi terhadap instansi, (3) mencegah terjadinya keresahan dikalangan karyawan yang selama ini kurang diperhatikan, (4) mengisi lowongan yang tersedia, akibat ada karyawan yang mutasi atau promosi, dan (5) 
mengoptimalkan penggunaan pengetahuan, kemampuan dan keterampilan karyawan sesuai dengan potensi yang bersangkutan.

Rivai juga menyebutkan perencanaan dan pengembangan karier adalah proses dimana dilakukan penyeleksian tujuan karier dan jenjang karier menuju tujuan-tujuan tersebut. Karier itu sendiri merupakan seluruh pekerjaan yang dimiliki atau dilakukan oleh individu selama masa hidupnya. Karier merupakan pola dari pekerjaan dan sangat berhubungan dengan pengalaman (posisi, wewenang, keputusan, interpretasi, subjektif atas pekerjaan ${ }^{5}$.

Bagian pengelola SDM dalam perusahaan amat menentukan proses pengembangan karir dalam suatu perusahaan. Bagian ini yang menyusun biaya dan kriteria yang baik sehingga dapat menjadi acuan dalam pengembangan karir seseorang dalam perusahaan. Setelah acuan tersebut disusun harus diinformasikan kepada seluruh karyawan agar mereka mempersiapkan diri untuk berusaha memenuhi kriteria tersebut.

Menjadi seorang pegawai adalah pilihan karir yang secara sadar harus dijalani dan dikembangkan sesuai dengan nilai, minat, dan keterampilan yang dimiliki. Untuk itu diperlukan perencanaan dan pengembangan karir agar potensi dan kemampuan yang dimiliki dapat bertumbuh dan teraktualisasi secara maksimal sebagai suatu proses yang disengaja oleh seseorang sehingga menjadi sadar akan atribut yang berhubungan dengan karir personal, dan akan merupakan rangkaian langkah sepanjang hidup yang menyumbang pada pemenuhan karirnya. Oleh karena itu, kegaiatan perencanaan, rekruitmen, dan pelatihan, memainkan peranan yang sangat penting dalam pengembangan karir seseorang.

Sehubungan dengan pembinaan mutu dan kinerja pegawai, maka diperlukan adanya rencana dan pengembangan karir pegawai secara memadai. Meskipun karir setiap orang bersifat unik, hal ini karena adanya proses perencanaan dan pengembangan karir yang jelas dapat membantu karyawan mengidentifikasikan sasaran-sasaran karir dan jalur karir yang dipilih menuju sasaran karir.

Menurut Siagian, 6 hal-hal yang diharapkan karyawan terhadap penerapan pengembangan karier yang dilakukan perusahaan, antara lain (1) adanya pelaksanaan yang adil dan benar, (2) adanya kepedulian para atasan langsung, (3) disebarkanluaskannya informasi tentang kesempatan promosi, (4) dilakukannya pengembangan minat untuk dipromosikan, (5) adanya perasaan puas dalam pengembangan karir.

Pelaksanan yang adil yang benar maksudnya adalah adanya pola yang jelas dijadikan pemegang dalam memberikan kesempatan kepada 
karyawan untuk berkarir tanpa membedakan satu sama lain. Hal ini bisa terjadi jika pengembangan karir itu sudah diatur sedemikian rupa dengan kriteria yang logis, rasional dan jauh dari tafsir subjektivitas.

Kepedulian para atasan langsung sangat diharapkan karyawan karena yang mengetahui kelemahan dan kelebihan seorang karyawan adalah atasanya langsung, sebab atasan tersebut selalu membimbing dan mengarahakan yang bersangkutan dalam melaksanakan tugas sehari-hari.

Informasi tentang perkembangan perusahaan ataupun hal-hal yang berkaitan dengan perbaikan nasib mereka akan dapat mendorong mereka untuk menentukan langkah-langkah pengembangan karir, meningkatnya prestasi kerja, dan berusaha memenuhi kriteria yang ditentukan untuk dapat lolos dalam kesempatan pengembangan karir. Dan sebaliknya, jika informasi tersebut tidak sampai pada karyawan dan tidak dapat menentukan sebenarnya yang dituntut perusahaan dalam peluang pengembangan karir tersebut.

Dilakukannya pengembangan minat untuk dipromosikan merupakan tugas dan kewajiban atasan karyawan yang bersangkutan,baik minat dan semangat kerja maupun minat yang menimbulkan gairah kerja, sehingga mereka turut berlomba dalam kesempatan pengembangan karir yang akan datang.

Rasa puas yang dirasakan setiap orang berbeda sesuai dengan tingkat kebutuhan dan keinginan yang bersangkutan. Setiap karyawan harus dapat mengukur tingkat kepuasannya dalam bekerja, sebab tingkat kepuasaan yang tinggi harus pula diikuti oleh kemampuan dan keterampilan kerja yang lebih tinggi.

Usaha-usaha yang dilakukan oleh bagian SDM untuk melaksanakan pengembangan karir diantaranya adalah menyusun perencanaan karir dengan melihat perusahaan secara keseluruhan, menyebarkanluaskan informasi tentang pola karir yang dipakai perusahaan, menghimpun data dari berbagai sumber tentang ihwal karyawan untuk pengembangan karir, serta melakukan telaah cara-cara yang tepat untuk digunakan dalam pengembangan karir.

\section{Penampilan Modis}

Penampilan modis pegawai bank dapat dilihat antara lain dari cara berpakaian. Saat bekerja, pakaian menjadi salah satu faktor penentu keberhasilan dalam berkarier dengan memperhatikan pakaian yang cocok di tempat kerja bila perusahaan tempat bekerja tidak memiliki seragam khusus. Intinya, berpakaian rapi dalam bekerja sesuai dengan tempat dimana pegawai bekerja. Gaya formal umumnya dipakai oleh pegawai 
yang berprofesi sebagai sekretaris, penasihat hukum, pegawai bank, pengajar, dan profesi lain yang bersifat resmi dan menuntut untuk bertemu dengan berbagai jenis kalangan. Untuk profesi ini sebaiknya mengenakan setelan dengan model yang tidak terlalu rumit. Pakaian dalam bentuk 'Two pieces' (dua bagian yang senada) dan menghindari corak ramai lebih mengesankan profesionalisme pegawai. Panjang rok bisa sedikit di atas atau di bawah lutut. Pemilihan warna - warna klasik untuk tata rias seperti cokelat, hitam, atau 'navy blue' lebih mengesankan citra elegan bagi perempuan. Gunakan sepatu dengan hak antara 5-7 cm. Lengkapi dengan aksesori secukupnya7.

Rickieno menyatakan bahwa orang yang penampilan fisiknya menarik cenderung dianggap memiliki kepribadian yang menarik pula, sepeti tenang, penuh kehangatan, penuh perhatian, pandai bersosialisasi, tidak memiliki sifat ketergantungan, dan hasil pekerjaan mereka umumnya dianggap baik pula. Percaya diri juga merupakan salah satu faktor yang dapat memberikan citra positif pegawai di depan rekan kerja8.

Aktualisasi fisik --untuk menonjolkan kesan apa yang akan disampaikan pada orang lain, percaya diri -- secara keseluruhan pegawai perempuan di Bank Danamon yang dapat terlihat elegan (pegawai bank terkesan berkelas), up to date (selalu mengikuti perkembangan mode), dan penampilan yang good looking atau enak dilihat orang lain dengan penampilan fisik simpel, sesuai bidang pekerjaan.

\section{Teori dan Konsep Gender}

Membahas permasalahan gender berarti membahas permasalahan perempuan dan juga laki-laki dalam kehidupan masyarakat. Dalam pembahasan mengenai gender, termasuk kesetaraan dan keadilan gender dikenal adanya 2 aliran atau teori yaitu teori nurture dan teori nature. Namun demikian, dapat pula dikembangkan satu konsep teori yang diilhami dari dua konsep teori tersebut yang merupakan kompromistis atau keseimbangan yang disebut dengan teori equilibrium.

Menurut teori nurture, adanya perbedaan perempuan dan laki-laki adalah hasil konstruksi sosial budaya sehingga menghasilkan peran dan tugas yang berbeda. Perbedaan itu membuat perempuan selalu tertinggal dan terabaikan peran dan kontribusinya dalam kehidupan berkeluarga, bermasyarakat, berbangsa dan bernegara. Konstruksi sosial menempatkan perempuan dan laki-laki dalam perbedaan kelas. Laki-laki diidentikkan dengan kelas borjuis, dan perempuan sebagai kelas proletar.

Menurut teori nature, adanya pembedaan laki-laki dan perempuan adalah kodrat, sehingga harus diterima. Perbedaan biologis itu 
memberikan indikasi dan implikasi bahwa diantara kedua jenis kelamin tersebut memiliki peran dan tugas yang berbeda. Ada peran dan tugas yang dapat dipertukarkan, tetapi ada yang tidak bisa karena memang berbeda secara kodrat alamiahnya.

Dalam proses perkembangannya, disadari bahwa ada beberapa kelemahan konsep nurture yang dirasa tidak menciptakan kedamaian dan keharmonisan dalam kehidupan berkeluarga maupun bermasyarakat, yaitu terjadi ketidakadilan gender, maka beralih ke teori nature. Akibat ketidakadilan gender dalam berbagai kehidupan lebih banyak dialami oleh perempuan, meskipun laki-laki juga mengalami dampaknya.

Disamping kedua aliran diatas, terdapat kompromistis yang dikenal dengan keseimbangan (equilibrium) yang menekankan pada konsep kemitraan dan keharmonisan dalam hubungan antara perempuan dengan laki-laki. Pandangan ini tidak mempertentangkan antara kaum perempuan dan laki-laki, karena keduanya harus bekerja sama dalam kemitraan dan keharmonisan dalam kehidupan keluarga, masyarakat, bangsa dan negara. Untuk mewujudkan gagasan tersebut, maka dalam setiap kebijakan dan strategi pembangunan agar diperhitungkan kepentingan dan peran perempuan dan laki-laki secara seimbang. Hubungan diantara kedua elemen tersebut bukan saling bertentangan tetapi hubungan komplementer guna saling melengkapi satu sama lain. R.H. Tawney menyebutkan bahwa keragaman peran apakah karena faktor biologis, etnis, aspirasi, minat, pilihan, atau budaya pada hakikatnya adalah realita kehidupan manusia.

Hubungan laki-laki dan perempuan bukan dilandasi konflik dikotomis, bukan pula struktural fungsional, tetapi lebih dilandasi kebutuhan kebersamaan guna membangun kemitraan yang hamonis, karena setiap pihak memiliki kelebihan sekaligus kelemahan yang perlu diisi dan dilengkapi pihak lain dalam kerjasama yang setara.

Istilah gender diketengahkan oleh para ilmuwan sosial untuk menjelaskan mana perbedaan perempuan dan laki-laki yang bersifat bawaan sebagai ciptaan Tuhan dan mana yang merupakan tuntutan budaya yang dikonstruksikan, dipelajari dan disosialisasikan. Pembedaan itu sangat penting, karena selama ini sering kali dicampuradukkan ciri-ciri manusia yang bersifat kodrati dan tidak berubah dengan ciri-ciri manusia yang bersifat non kodrati (gender) yang sebenarnya bisa berubah-ubah atau diubah.

Pembedaan peran gender ini sangat membantu untuk memikirkan kembali tentang pembagian peran yang selama ini dianggap telah melekat pada perempuan dan laki-laki. Perbedaan gender dikenal sebagai sesuatu 
yang tidak tetap, tidak permanen, memudahkan untuk membangun gambaran tentang realitas relasi perempuan dan laki-laki yang dinamis yang lebih tepat dan cocok dengan kenyataan yang ada dalam masyarakat.

Di lain pihak, alat analisis sosial yang telah ada seperti analisis kelas, analisis diskursus (discourse analysis), dan analisis kebudayaan, yang selama ini digunakan untuk memahami realitas sosial tidak dapat menangkap realitas adanya relasi kekuasaan yang didasarkan pada relasi gender dan sangat berpotensi menumbuhkan penindasan. Dengan begitu analisis gender sebenarnya menggenapi sekaligus mengkoreksi alat analisis sosial yang ada yang dapat digunakan untuk meneropong realitas relasi sosial lelaki dan perempuan serta akibat-akibat yang ditimbulkannya.

Dengan demikian, jelaslah mengapa gender perlu dipersoalkan. Perbedaan konsep gender secara sosial telah melahirkan perbedaan peran perempuan dan laki-laki dalam masyarakat. Secara umum, adanya gender telah melahirkan perbedaan peran, tanggung jawab, fungsi, dan bahkan ruang tempat dimana manusia beraktifitas. Sedemikian rupanya perbedaan gender itu melekat pada cara pandang masyarakat, sehingga masyarakat sering lupa seakan-akan hal itu merupakan sesuatu yang permanen dan abadi sebagaimana permanen dan abadinya ciri-ciri biologis yang dimiliki oleh perempuan dan laki-laki.

Secara sederhana perbedaan gender telah melahirkan pembedaan peran. Sifat dan fungsi yang berpola sebagai; (1) konstruksi biologis dari ciri primer, skunder, maskulin, feminim, (2) konstruksi sosial dari peran citra baku (stereotype), (3) konsruksi agama dari keyakinan kitab suci agama.

Anggapan bahwa sikap perempuan feminim dan laki-laki maskulin bukanlah sesuatu yang mutlak, semutlak kepemilikan manusia atas jenis kelamin biologisnya.

Dengan demikian gender adalah perbedaan peran laki-laki dan perempuan yang dibentuk, dibuat, dan dikonstruksi oleh masyarakat dan dapat berubah sesuai dengan perkembangan zaman. Untuk memahami konsep gender, harus dibedakan antara kata gender dengan kata sex.

Sex adalah perbedaan jenis kelamin yang ditentukan secara biologis, yang secara fisik melekat pada masing-masing jenis kelamin, laki-laki dan perempuan. Perbedaan jenis kelamin merupakan kodrat atau ketentuan Tuhan, sehingga sifatnya permanen dan universal. 
Dalam memahami konsep gender ada beberapa hal yang perlu difahami, antara lain (1) ketidakadilan dan diskriminasi gender serta (2) kesetaraan gender.

Ketidakadilan dan diskriminasi gender merupakan kondisi tidak adil akibat dari sistem dan struktur sosial dimana baik perempuan maupun laki-laki menjadi korban dari sistem tersebut. Berbagai pembedaan peran dan kedudukan antara perempuan dan laki-laki baik secara langsung yang berupa perlakuan maupun sikap dan yang tidak langsung berupa dampak suatu peraturan perundang-undangan maupun kebijakan telah menimbulkan berbagai ketidak-adilan yang berakar dalam sejarah, adat, norma, ataupun dalam berbagai struktur yang ada dalam masyarakat.

Ketidakadilan gender terjadi karena adanya keyakinan dan pembenaran yang ditanamkan sepanjang peradaban manusia dalam berbagai bentuk yang bukan hanya menimpa perempuan saja tetapi juga dialami oleh laki-laki. Meskipun secara agregat ketidak-adilan gender dalam berbagai kehidupan ini lebih banyak dialami oleh perempuan, namun hal itu berdampak pula terhadap laki-laki.

Bentuk-bentuk ketidak-adilan akibat diskriminasi itu meliputi: (1) marginalisasi (peminggiran/pemiskinan) perempuan yang mengakibatkan kemiskinan, banyak terjadi dalam masyarakat di negara berkembang seperti penggusuran dari kampung halaman, eksploitasi, banyak perempuan tersingkir dan menjadi miskin akibat dari program pembangunan seperti intensifikasi pertanian yang hanya memfokuskan pada petani laki-laki, (2) subordinasi, pada dasarnya adalah keyakinan bahwa salah satu jenis kelamin dianggap lebih penting atau lebih utama dibanding jenis kelamin lainnya. Ada pandangan yang menempatkan kedudukan perempuan lebih rendah daripada laki-laki. (3) stereotype, merupakan pelabelan atau penandaan yang sering kali bersifat negatif secara umum selalu melahirkan ketidak-adilan pada salah satu jenis kelamin tertentu. (4) kekerasan (violence), artinya suatu serangan fisik maupun serangan non fisik yang dialami perempuan maupun laki-laki sehingga yang mengalami akan terusik batinnya. (5) beban kerja (double burden), yaitu sebagai suatu bentuk diskriminasi dan ketidak-adilan gender dimana beberapa beban kegiatan diemban lebih banyak oleh salah satu jenis kelamin.

Kesetaraan dan keadilan gender adalah suatu kondisi dimana porsi dan siklus sosial perempuan dan laki-laki setara, seimbang dan harmonis. Kondisi ini dapat terwujud apabila terdapat perlakuan adil antara perempuan dan laki-laki. Penerapan kesetaraan dan keadilan gender 
harus memperhatikan masalah kontekstual dan situasional, bukan berdasarkan perhitungan secara sistematis dan tidak bersifat universal.

\section{HASIL PENELITIAN}

\section{Uji Normalitas}

Uji normalitas bertujuan untuk mengetahui apakah distribusi sebuah data mengikuti atau mendekati distribusi normal. Data yang baik adalah yang mempunyai pola seperti distribusi normal (tidak melenceng ke kiri dan ke kanan). Dari hasil pengolahan data dengan metode SPSS dapat dikemukakan bahwa nilai-nilai sebaran data terletak di sekitar garis lurus, sehingga persyaratan normalitas dapat dipenuhi seperti terlihat pada lampiran.

\section{Uji Validitas}

Uji validitas daftar pertanyaan dilakukan dengan tujuan untuk mengetahui kehandalan angket. Kehandalan angket mempunyai arti bahwa angket mampu mengukur apa yang seharusnya diukur. Dari hasil pengolahan data mengenai indikator-indikator yang diteliti, diperoleh hasil bahwa semua butir pertanyaan adalah valid karena lebih besar dari $r$ tabel.

\section{Uji Reliabilitas}

Setelah dilakukan uji validitasnya kemudian perlu diketahui uji reliabilitas. Uji reliabilitas ini ditunjukkan dari hasil koefisien Alpha Cronmbach dengan hasil. Nilai Alpha ini >0,6 yang dapat dikatakan bahwa dari seluruh indikator memiliki reliabilitas yang tinggi.

\section{Pembuktian Hipotesis}

Pembuktian hipotesis digunakan untuk melihat pengaruh variabel penampilan modis terhadap variabel terikatnya dalam hal ini adalah pengembangan karir. Berdasarkan hasil perhitungan melalui komputer dengan menggunakan program SPSS, maka diperoleh data-data perhitungan sebagai berikut :

Koefisien Regresi Tentang Pengaruh Penampilan Modis Terhadap Pengembangan Karir

\begin{tabular}{ccccc}
\hline Variabel & $\begin{array}{c}\text { Koefisien } \\
\text { Regresi }\end{array}$ & $\begin{array}{c}\text { Standar } \\
\text { Error }\end{array}$ & $\mathbf{t}$ & Sig \\
\hline Constant & 0,890 & 0,330 & 2,694 & 0,012 \\
$X$ & 0,699 & 0,091 & 7,610 & 0,000 \\
\hline
\end{tabular}




\begin{tabular}{ll} 
R Squared & $=0,674$ \\
F Ratio & $=57,906$ \\
Sig. & $=0,000$ \\
\hline
\end{tabular}

Sumber : Data Primer

Berdasarkan tabel diatas diperoleh koefisien determinasi berganda ( $\mathrm{R}$ squared) yang diperoleh dari kelipatan ( $\mathrm{R}$ ) adalah sebesar 0,674 menunjukkan bahwa 67,4\% pengembangan karir (Y) bisa diterangkan dengan variabel penampilan modis $(X)$ sedangkan sisanya $(100 \%-67,4 \%=$ $32,6 \%$ ) dapat diterangkan oleh variabel lain yang tidak diteliti pada penelitian ini.

Penggunaan teknik analisis data regresi linier sederhana (simple regression analysis) pada penelitian ini dimaksudkan untuk mencari hubungan antara variabel bebas yaitu variabel penampilan modis $(X)$ terhadap variabel terikat yaitu pengembangan karir.

Berdasarkan kepada tabel diatas maka diperoleh model persamaan regresi linier berganda sebagai berikut : $Y=0,890+0,699 X$.

Koefisien regresi dari variabel bebas $\mathrm{b}$ bertanda positif $(+)$. Dimana hal ini berarti apabila variabel penampilan modis (b) ditingkatkan perannya maka akan menimbulkan peningkatan pula pada variabel terikatnya.

Persamaan di atas menunjukkan bahwa koefisien regresi variabel penampilan modis $(X)=0,699$ ini menunjukkan besarnya pengaruh variabel tersebut terhadap pengembangan karir karyawan perempuan pada Bank Danamon Cabang Pekanbaru. Tanda positif menunjukkan koefisien arah hubungan yang positif. Dengan arti setiap ada kenaikan satu satuan variabel penampilan modis maka pengembangan karir akan naik sebesar 0,699 kali dengan anggapan faktor yang lain konstan (ceteris paribus).

Selanjutnya untuk membuktikan secara keseluruhan apakah variabel bebas secara bersama-sama mempunyai pengaruh terhadap variabel terikat maka digunakan uji-F, dengan ketentuan jika $\mathrm{F}$ hitung $>\mathrm{F}$ tabel maka terdapat hubungan/pengaruh antara variabel bebas dengan variabel terikatnya dan sebaliknya jika $\mathrm{F}$ hitung $<\mathrm{F}$ tabel maka tidak terdapat pengaruh atau dengan kata lain variabel bebas tidak dapat menerangkan variabel tidak bebasnya (Variabel terikat).

Dari tabel diatas diperoleh $\mathrm{F}$ hitung adalah sebesar 57,906 dan dengan tingkat signifikan sebesar 0,000 , sedangkan $\mathrm{F}$ tabel dengan tingkat signifikan $\alpha 0,05=4,17$. Jadi dapat disimpulkan bahwa $F$ hitung lebih besar dari F tabel $(57,906>4,17)$. 
Dengan demikian hipotesis yang didukung dengan variabel bebas dalam penelitian ini mempunyai pengaruh signifikan terhadap pengembangan karir karyawan perempuan pada Bank Danamon Cabang Pekanbaru dapat diterima kebenarannya.

\section{PEMBAHASAN}

Sebelumnya telah dilakukan pembuktian terhadap hipotesis dengan menghimpun data yang diperoleh dari para responden dan diolah dengan bantuan komputer yaitu program SPSS sehingga dapat dijelaskan pengaruh penampilan modis terhadap pengembangan karir karyawan perempuan pada Bank Danamon Cabang Pekanbaru, berikut ini dilanjutkan dengan pembahasan hasil analisis.

Dari hasil penelitian, diperoleh bahwa penampilan modis karyawan perempuan di Bank Danamon Cabang Pekanbaru berpengaruh terhadap pengembangan karir karyawan. Indikator-indikator yang termasuk dalam variabel penampilan modis ini terdiri dari cara berpakaian, dandanan yang terkesan menarik untuk dilihat orang lain, penggunaan barang-barang branded, penampilan yang up to date, mengikuti trend mode saat ini, penampilan yang rapi dan berwibawa. Karyawan perempuan di Bank Danamon Cabang Pekanbaru menggambarkan penampilan modis dari segi visual yang jelas tampak dari penampilan sehari-hari di kantor. Pengetahuan responden mengenai penampilan modis pada umumnya berkisar pada cara berpakaian, berdandan yang up to date.

Secara umum, karyawan Bank Danamon Cabang Pekanbaru mengetahui bahwa bank tempat ia bekerja memiliki peraturan mengenai tata cara berpenampilan di kantor. Sebab, setiap karyawan diberikan buku panduan berupa tata cara berpenampilan yang pantas yang diberikan sejak awal ia mulai bekerja atau pada saat dilakukannya pelatihan layanan oleh kantornya, sehingga penampilan modis pada pegawai perempuan di Bank Danamon Cabang Pekanbaru cukup dominan. Baik dalam berpakaian, make up, dan penggunaan barang - barang branded, responden tidak lepas dari adanya peraturan untuk memperhatikan penampilan sehingga terlihat good looking di hadapan klien maupun nasabah.

Selanjutnya untuk pengaruh penampilan modis terhadap pengembangan karir karyawan, ternyata, berdasarkan hasil penleitian terlihat bahwa baik buruknya penampilan karyawan perempuan di kantor sebagian besar berpengaruh terhadap kariernya. Pengaruh ini dapat dilihat dari keseharian pegawai karyawan dalam menjalankan pekerjaannya dengan berpenampilan baik dan cukup modis sehingga 
nasabah pun tertarik dan merasa nyaman dengan layanan yang diberikan, juga atas asumsi bahwa perempuan yang berpenampilan menarik cenderung lebih supel, penuh kehangatan sehingga layanan yang diberikan pun memberikan kepuasan kepada nasabah.

Penampilan seorang karyawan merupakan salah satu aspek dari layanan yang baik kepada nasabah, klien maupun rekan kerja. Bekerja di bank merupakan pekerjaan yang menuntut karyawannya memiliki intensitas cukup sering berinteraksi dengan orang lain. Penampilan tentu menjadi aspek utama secara visual yang paling dominan diperhatikan. Lalu, didukung dengan aspek-aspek layanan lainnya sehingga hal ini menjadi penting untuk menjadi penilaian utama pada kinerja.

\section{SIMPULAN}

Berdasarkan hasil analisis dan pembahasan sebelumnya, berikut ini dikemukakan beberapa kesimpulan sebagai berikut: (1) berdasarkan hasil penelitian, diperoleh bahwa penampilan modis berpengaruh signifikan terhadap pengembangan karir karyawan perempuan pada Bank Danamon Cabang Pekanbaru, (2) menjaga penampilan di kantor merupakan penilaian utama individu sebagai aspek dari layanan prima pegawai, khususnya pegawai perempuan. Gaya luwes, hangat dan mendetail adalah milik dari perempuan sebagai suatu hal yang bersifat nurture, sebagai hasil konstruksi sosial yang terbentuk sudah sejak lama, sehingga pegawai perempuan lebih banyak menduduki posisi frontliner dibanding pegawai laki-laki.

Sehubungan dengan hal diatas, karyawan perempuan memang sudah selayaknya untuk tetap menjaga penampilan agar menarik dan membuat interaksi antara pegawai dan nasabah lebih hangat dan terasa nyaman, namun penampilan yang diberikan adalah penampilan yang tidak berlebihan. Oleh karena penampilan merupakan bagian dari salah satu penilaian kinerja individu, maka hal ini dapat digunakan pegawai perempuan sebagai kesempatan untuk semakin meningkatkan kualitas kinerja di kantor.

\section{Endnotes:}

1 www.forumkami.com, 21 Desember 2009.

2 Rickieno, Rizal, Menjadi Karyawan Idaman Dalam 4 Minggu, Penerbit Mutiara Benua, Jakarta, 2008, hal. 57

3 Sari, Nurahadian, Cerdas Sukses Dalam Berkarir, Penerbit Jaya Abadi, Jakarta, 2006, hal. 48 
4 Riva'i Veithzal, Manajemen Sumber Daya Manusia Untuk Perusahaan, Teori dan Praktik, Edisi 1, PT Raja Grafindo Persada, Jakarta, 2004, hal. 209.

5 Riva'i Veithzal, Manajemen Sumber Daya Manusia Untuk Perusahaan, Teori dan Praktik, Edisi 1, PT Raja Grafindo Persada, Jakarta, 2004, hal. 284

6 Siagian, Sondang P, Management Sumber Daya Manusia.Gunung Agung, Jakarta, 1997

7 http://www.loundrian.com

8 Rickieno, Rizal, Menjadi Karyawan Idaman Dalam 4 Minggu, Penerbit Mutiara Benua, Jakarta, 2008

\section{DAFTAR PUSTAKA}

Arikunto, Suharsimi. 1997. Prosedur Penelitian Suatu Pendekatan Praktek. Jakarta: Rineka Cipta.

Asy-Syadzili, Karim. 2008. Inspiring Women, Rahasia Dibalik Wanita Sukses. Jakarta: Khalifa.

Bungin, Burhan. 2008. Sosiologi Komunikasi. Jakarta: Kencana Penada Media Group

Dessler, Gary. 2006. Manajemen Sumber Daya Manusia Jilid I. Jakarta: Indeks.

Fakih, Mansour. 1996. Analisis Gender dan Transformasi Sosial. Yogyakarta: Pustaka Pelajar.

Gibson, Imam, 2005, Organisasi Perlaku Struktur dan Proses (Terjemahan) Bina Rupa Aksara, Jakarta.

Gomes, Fautino Cardoso, Manajement Sumberdaya Manusia, Andi offset, Yogyakarta, 2000

Ghozali, Imam. 2005, Analisis Multivarite dengan Program SPSS, Badan Penerbitan Universitas Diponegoro, Semarang

Husein, Umar, 1999, Riset Manajement Sumber Daya Manusia Dalam Organisasi,Gramedia Utama, Jakarta.

Lubis, Kusrinayanti. 2007. Gambaran Kapitalisme Media Elektronik Pada Citra Cantik dan Modis Siswi SMU Di Medan. Skripsi (tidak diterbitkan). Medan.

Megawangi, Ratna. 1999. Membiarkan Berbeda. Bandung: Penerbit Mizan.

Murniati, A. Nunuk. 2004. P. Getar Gender (Perempuan Indonesia Dalam Perspektif Agama, Budaya, Keluarga). Magelang: Indonesiatera. 
Prasetyo, Harry, R. 2004. 2O Langkah Mudah Untuk Sukses Berkarier. Jakarta: Elex Media Komputindo.

Rickieno, Rizal. 2008. Menjadi Karyawan Idaman dalam 4 Minggu. Tangerang: Mutiara Benua. 2008

Sari, Nurahadian. 2006. Cerdas Sukses dalam Berkarir !. Jakarta: Dani Jaya Abadi.

Santoso, Anang. 2009. Bahasa Perempuan, Sebuah Ideologi Perjuangan. Jakarta: Bumi Aksara.

Sugiyono. 2006. Metode Penelitian Kuantitatif Kualitatif dan RED. Bandung: Alfabeta.

Zulganef. Metode Penelitian Sosial dan Bisnis.Yogyakarta. Graha Ilmu. 2008 